\title{
Article
}

http://dx.doi.org/10.11646/phytotaxa.181.5.2

\section{When the old guys knew better: The true identity of Mimosa longepedunculata and reestablishment of $M$. tocantina (Leguminosae, Mimosoideae)}

\section{LEONARDO MAURICI BORGES* \& JOSÉ RUBENS PIRANI}

Laboratório de Sistemática Vegetal, Departamento de Botânica, Instituto de Biociências, Universidade de São Paulo, São Paulo, Brazil *Corresponding author: aquitemcaqui@gmail.com

\begin{abstract}
Megadiverse genera usually have a complex taxonomy. One factor influencing this complexity is concerned to synonyms, which are often numerous in widespread and morphologically variable species. In this article we examined the case of $M i-$ mosa longepedunculata and $M$. tocantina, two sympatric narrowly distributed species from central Brazil, considered to be synonyms in Barneby's monograph. We show that this was an inaccurate taxonomic decision related to a misinterpretation of the type specimens and, possibly, also to sampling biases in field works. The definition of each species is here clarified and M. tocantina is reestablished and considered a distinct species from M. longepedunculata, having M. pseudosetosa as a new synonym. A regional identification key for the species is provided together with data on distribution and habitat, flowering and fruiting, conservation status, etymology, and notes on morphology. Illustrations, pictures and a full description of $M$. longepedunculata are also presented.
\end{abstract}

Keywords: Ernst Ule, Fabaceae, Nomenclature, Paul Taubert, Rupert Barneby, Taxonomy

\section{Introduction}

Mimosa Linnaeus (1753: 516) is a megadiverse genus with more than 500 species (Barneby 1991, Luckow 2005). According to Berry et al. (2005), megadiverse genera have long been avoided by botanists because of their complex taxonomy, wide geographic range and large contingent. Nevertheless, Neotropical Mimosa were fully revised and monographed by Barneby (1991), and since then, several new taxa have been described (e.g., Dutra \& Garcia 2012; Grings \& Ribas 2013; Morales et al. 2013; Särkinen et al. 2011; Savassi-Coutinho et al. 2012; Silva et al. 2011; Simon et al. 2010). The genus is mainly distributed in the Neotropical region and has two major centers of diversity, being one in Mexico and the other in Central Brazil (Luckow 2005).

It is not uncommon for such "giant genera" to also have species with a large number of synonyms due to the description of the same taxonomic entities by different authors and with different names. Within Mimosa, this is observed in species showing large morphological variability associated with a wide distribution area, such as $M$. pigra Linnaeus (1755: 13-14), a weedy species that has 15 names under synonymy (Barneby 1991; treated as M. pellita Humb. \& Bonpl. ex Willd. [1806: 1037-1038]). However, most species in the genus are microendemics; therefore, in the few cases where a list of synonyms does exist, it is usually very small.

Nonetheless, the congruence of such factors as large number of species, existence of synonyms, and classification mainly based on micro characters demands extra care when describing new taxa in Mimosa in order to avoid inaccurate conclusions. Here we relate how the scanty type collection of one species belonging to this giant genus led a skillful author such as Rupert Barneby to make a mistaken taxonomic decision.

\section{A mysterious plant}

Chapada dos Veadeiros is a mountainous complex in central Brazil ranging from 800 to $1650 \mathrm{~m}$ in elevation (Munhoz \& Felfili 2006). It is located about $300 \mathrm{~km}$ to the north of Brasilia in the State of Goiás. Even though this high flat plain region is included in the Cerrado Domain, where savanna physiognomies prevail, its elevated areas are mostly covered by "campos rupestres", a type of vegetation found elsewhere in Brazil on sandy to rocky soils, showing 
We have stressed here that fieldwork is a crucial part of taxonomy. However, in the midst of a biodiversity crisis, systematists are mostly focused on punctual collections of particular groups, aiming specially for sampling genetic material. It seems that future development of taxonomy requires a shift in that practice to the execution of well-planed expeditions focused on general collections covering areas poorly or unevenly explored, which will allow us to frame a more comprehensive picture of the flora.

\section{Acknowledgments}

We are grateful to the curators of CEN, HBG, NY, P, R, SPF and UB herbaria for providing access to the collections and loans of specimens, particularly Matthias Schultz and Norbert Jürgens from HBG, Marc Jeanson and Odile Poncy from P, and Vera Lúcia C. Martins from R for kindly providing and allowing use of type images; Kay Killmann for help with German translation; and two anonymous reviewers and the editor V.F. Mansano for comments on an early version of this paper. LMB thanks M.T.C. Watanabe, P.C. Baleeiro, B. Loeuille and J.B.A. Bringel for help in the field; also, FAPESP (2010/11093-1), FAPESP (2013/ 13709-8) and NSF DBI (074975) for support. JRP is supported by CNPq. This work is dedicated to E.H.G. Ule, P.H.W. Taubert and R.C. Barneby.

\section{Literature Cited}

Bachman, S., Moat, J., Hill, A.W., de Torre, J. \& Scott, B. (2011) Supporting Red List threat assessments with GeoCAT: geospatial conservation assessment tool. ZooKeys 126: 117-26.

http://dx.doi.org/10.3897/zookeys.150.2109

Barneby, R.C. (1991) Sensitivae censitae: a description of the genus Mimosa Linnaeus (Mimosaceae) in the New World. Memoirs of the New York Botanical Garden 65: 1-835.

Barneby, R.C. (1993) Increments to the genus Mimosa (Mimosaceae) from South America. Brittonia 45: 328-332. http://dx.doi.org/10.2307/2807606

Barneby, R.C. (1997) Toward a census of genus Mimosa (Mimosaceae) in the Americas: a new species from Mexico (Baja California Sur) and two from planaltine Brazil (Goiás, Minas Gerais). Brittonia 49: 452-457.

http://dx.doi.org/10.2307/2807733

Bentham, G. (1842) Notes on Mimoseae, with a short Synopsis of Species. Journal of botany: being a second series of the Botanical miscellany 4: 323-418.

Bentham, G. (1875) Revision of the Suborder Mimoseae. Transactions of the Linnean Society 30: 335-644. http://dx.doi.org/10.1111/j.1096-3642.1875.tb00005.x

Berry, P.E., Hipp, A.L., Wurdack, K.J., Ee, B. Van \& Riina, R. (2005) Molecular phylogenetics of the giant genus Croton and tribe Crotoneae (Euphorbiaceae sensu stricto) using ITS and TRNL-TRNF DNA sequence data. American Journal of Botany 92: 15201534 .

http://dx.doi.org/10.3732/ajb.92.9.1520

Borges, L.M. \& Pirani, J.R. (2014) Busted ghosts: Rediscovery of supposedly destroyed types of Brazilian Mimosa (Leguminosae, Mimosoideae). Phytotaxa 177(2): 207-220.

http://dx.doi.org/10.11646/phytotaxa.177.4.2

Cavalcanti, T.B. (2007) Novas espécies de Diplusodon Pohl (Lythraceae) do Planalto Central e Estado de Minas Gerais, Brasil. Acta Botanica Brasilica 21: 807-812. http://dx.doi.org/10.1590/S0102-33062007000400005

Dutra, V.F. \& Garcia, F.C.P. (2012) Two new species and one new variety of Mimosa sect. Habbasia (Leguminosae: Mimosoideae) from Central Brazil. Kew Bulletin 68: 1-9.

Giulietti, A.M. \& Pirani, J.R. (1988) Patterns of geographic distribution of some plant species from the Espinhaço Range, Minas Gerais and Bahia, Brazil. In: Vanzolini, P.E. \& Heyer, W.R. (eds.) Proceedings of a workshop on neotropical distribution patterns. Academia Brasileira de Ciências, Rio de Janeiro, pp. 39-69.

Grings, M. \& Ribas, O.S. (2013) Mimosa sobralii (Fabaceae, Mimosoideae), a new tree species endemic to the southern Brazilian highland slopes. Phytotaxa 131: 23-28.

http://dx.doi.org/10.11646/phytotaxa.131.1.4 
Harris, J.G. \& Harris, M.W. (2001) Plant Identification Terminology. 2nd ed. Spring Lake Publishing, Spring Lake, 206 pp.

Linnaeus, C. (1753) Species Plantarum 2. Stockholm. Laurentius Salvius, Stockholm, pp. 561-1200.

Linnaeus, C. (1755) Centuria I. Plantarum. Exc. L.M. Höjer, Reg. Acad. Typogr, Upsasa, 36 pp.

Luckow, M.A. (2005) Tribe Mimoseae. In: Lewis, G.P., Schrire, B. Mackinder, B. \& Lock, M. (Eds.) Legumes of the world. Royal Botanical Gardens, Kew, pp. 163-183.

Madeira, J.A., Ribeiro, K.T., Oliveira, M.J.R., Nascimento, J.S. \& Paiva, C.L. (2008) Distribuição espacial do esforço de pesquisa biológica na Serra do Cipó, Minas Gerais: subsídios ao manejo das unidades de conservação da região. Megadiversidade 4: $233-247$.

McNeill, J., Barrie, F.R., Buck, W.R., Demoulin, V., Greuter, W., Hawksworth, D.L., Herendeen, P.S., Knapp, S., Marhold, K., Prado, J., Prud'homme van Reine, W.F., Smith, G.F., Wiersema, J.H. \& Turland, N.J. (Eds.) (2012) International Code of Nomenclature for algae, fungi, and plants (Melbourne Code): Adopted by the Eighteenth International Botanical Congress Melbourne, Australia, July 2011. Regnum Veg. Koeltz Scientific Books, Königstein, 208 pp.

Morales, M., Santos-Silva, J. \& Ribas, O. (2013) A new species of Mimosa sect. Mimosa (Leguminosae, Mimosoideae) from Southern Brazil. Brittonia 65: 148-153. http://dx.doi.org/10.1007/s12228-012-9273-x

Munhoz, C.B.R. \& Felfili, J.M. (2006) Floristics of the Herbaceous and Subshrub Layer of a Moist Grassland in the Cerrado Biosphere Reserve (Alto Paraíso De Goiás), Brazil. Edinburgh Journal of Botany 63: 343. http://dx.doi.org/10.1017/S0960428606000539.

Pastore, J.F.B. \& Marques, M.C.M. (2009) Duas novas espécies de Polygala (Polygalaceae) da região da Chapada dos Veadeiros, GO, Brasil. Acta Botanica Brasilica 23: 446-450.

http://dx.doi.org/10.1590/s0102-33062009000200016

Quantum GIS Development Team (2012) Quantum GIS Geographic Information System. Version 1.8.0.

Radford, A.E., Dickison, W.C., Massey, J.R. \& Bell, C.R. (1976) Vascular Plant Systematics. Harper and Row, New York, 891 pp.

Rapini, A., Ribeiro, P.L., Lambert, S. \& Pirani, J.R. (2008) A flora dos campos rupestres da Cadeia do Espinhaço. Megadiversidade 4: 15-23.

Särkinen, T.E., Luis, J., Peña, M., Yomona, A.D., Simon, M.F., Pennington, R.T. \& Hughes, C.E. (2011) Underestimated endemic species diversity in the dry inter-Andean valley of the Río Marañon, northern Peru: An example from Mimosa. Taxon 60: 139-150.

Savassi-Coutinho, A.P., Lewis, G.P. \& Souza, V.C. (2012) Mimosa roseoalba (Leguminosae : Mimosoideae), a new species from Mato Grosso do Sul, Brazil. Kew Bulletin 67: 827-831.

http://dx.doi.org/10.1007/s12225-012-9417-x

Silva, R.R. \& Tozzi, A.M.G.A. (2011) Uma nova espécie de Mimosa L . (Leguminosae, Mimosoideae) do Centro-Oeste do Brasil. Hoehnea 38: $143-146$.

http://dx.doi.org/10.1590/s2236-89062011000100013

Simon, M.F., Hughes, C.E. \& Harris, S.A. (2010) Four New Species of Mimosa (Leguminosae) from the Central Highlands of Brazil. Sistematic Botany 35: 277-288. http://dx.doi.org/10.1600/036364410791638333

Simon, M.F. \& Proença, C. (2000) Phytogeographic patterns of Mimosa (Mimosoideae, Leguminosae) in the Cerrado biome of Brazil: an indicator genus of high-altitude centers of endemism? Biological Conservation 96: 279-296. http://dx.doi.org/10.1016/s0006-3207(00)00085-9

Stafleu, F.A. \& Cowan, R.S. (1986) Taxonomic literature: a selective guide to botanical publications and collections with dates, commentaries and types (TL2). Volume VI: Sti-Vuy. Second. Bohn, Scheltema \& Holkema, Utrecht, 926 pp.

Taubert, P.H.W. (1896) Beiträge zur Kenntnis der Flora des centralbrasilianischen Staates Goyaz. Mit einer pflanzengeographischen Skizze von E. Ule. (Mit Tafel II u. Ill). Botanische Jahrbücher fur Systematik, Pflanzengeschichte und Pflanzengeographie 21: $402-457$.

Urban, I. (1906) Vitae Itineraque Collectorum Botanicorum, Notae Collaboratorum Biographicae. In: Martius, C.F.P. (Ed.) Flora Brasiliensis 1, Part 1, Fasc. CXXX., pp. 1-212.

West-Eberhard, M.J. (2005) Developmental plasticity and the origin of species differences. Proceedings of the National Academy of Sciences of the United States of America 102: 6543-6549.

http://dx.doi.org/10.1073/pnas.0501844102

Willdenow, K.L. (1806) Caroli Linnaei Species plantarum: exhibentes plantas rite cognitas, ad genera relatas, cum differentiis specificis, nominibus trivialibus, synonymis selectis, locis natalibus, secundum systema sexuale digestas. Vol. 4 (2). Impensis G.C. Nauk, Berlin, 495 pp. 